Squalen Bull. of Mar. \& Fish. Postharvest \& Biotech. 10 (1) 2015, 27-34
Squalen Bulletin of Marine \& Fisheries Postharvest \& Biotechnology
ISSN: 2089-5690
e-ISSN: 2406-9272

\title{
CHEMICAL COMPOSITION AND FATTY ACID PROFILE OF SOME INDONESIAN SEA CUCUMBERS
}

\author{
Yusro Nuri Fawzya*, Hedi Indra Januar, Rini Susilowati, and Ekowati Chasanah \\ Research and Development Center for Marine and Fisheries Product Processing and Biotechnology, \\ Jalan KS. Tubun, Petamburan VI, Slipi, Central Jakarta 10260, Indonesia \\ Article history: \\ Received: 8 December 2014; Revised: 2 March 2015; Accepted: 12 April 2015
}

\begin{abstract}
Indonesia has a great sea cucumber resource which is useful as functional food. Even though much information about the biopotency of sea cucumbers have been published, however, studies on nutrition value of Indonesian sea cucumbers are still beneficial due to the great diversity and uniqueness of each species. The present work was intended to obtain information about chemical composition and fatty acid profile of 4 (four) types of sea cucumbers which are frequently found in Halmahera water, North Maluku (Molucca), one of sea cucumbers producing area in Indonesia. The samples coded as $\mathrm{H}-03, \mathrm{H}-04, \mathrm{H}-05$ and $\mathrm{H}-10$, were identified as Bohadschia argus, Holothuria fuscogilva, Thelenota ananas, and Actinophyga lecanora. All sea cucumbers showed high protein content, more than $60 \%$ (drybase/db), except for $T$. ananas which had the lowest protein content $(48.26 \% \mathrm{db})$. As for fats, $T$. ananas showed the highest amount $(2.35 \% \mathrm{db})$ with dominated saturated fatty acids (SFA). On the other side, A. lecanora showed higher value of PUFA compared to SFA and MUFA. Palmitic acid (C16:0) was the most abundant SFA in the most samples with the amount of $0.49-4.9 \mathrm{mg} / \mathrm{g}$ sample. Among PUFA, eicosapentaenoic acid/EPA (C20:5n3) was detected, and eicosatrienoic acid $(\mathrm{C} 20: 3 \mathrm{n} 6)$ was relatively higher than the others. The ratio of $\omega 6 / \omega 3$ fatty acid was 1.2-3.2 showing that total $\omega 6$ fatty acid was higher than total $\omega 3$ fatty acid. However, this value is safe enough to protect against chronic and degenerative diseases.
\end{abstract}

Keywords: Indonesian sea cucumbers, chemical composition, fatty acid profile

\section{Introduction}

Sea cucumber is one of the fishery products which has high nutrition value and commonly used as functional food. A number of bioactivities of sea cucumbers have been reported, including antioxidant (Zhong et al., 2007), antitumor (Zhang \& Yi, 2011; Januar et al., 2014; Aminin et al., 2015) antimicrobial (Jiang et al., 2014) and anti-inflammatory (Bordbar et al., 2011). These activities are referred to the presence of bioactive compounds especially saponins, chondroitin sulfates, phenolics, essential fatty acids and others. Indonesia has approximately 53 types of sea cucumbers, 29 of those were internationally traded, which were mostly Holoturiidae and Stichopodidae (Darsono, 2007). The export of these sea cucumbers reached about 2600 ton in 2010 (Anon., 2010), in dried product form. The main market for Indonesia sea cucumbers are mostly China, Japan, Korea, Singapore, Taiwan, and Australia (Sukmiwati, 2012). The Indonesian sea cucumber export were

${ }^{*}$ Corresponding author.

E-mail: nuri_fawzya@gmail.com conducted by 81 firms, the largest number of sea cucumber exporter in the world (Brown et al., 2010). Sea cucumber can be found in nearly all aquatic coast, in shallow tidal areas to deep water. The producing area of Indonesian sea cucumbers are Bangka, Sulawesi, Maluku, West Nusa Tenggara Barat (Sumbawa), East Nusa Tenggara (Flores and Sumba) and Papua (Martoyo et al., 2006).

Variation of the nature and nutritional value of sea cucumbers will affect on their utilization and their economic values as well. Several publications reported about various types and the distribution of sea cucumbers in Indonesia (Yusron, 2004; Purwati, 2005; Elfidasari et al., 2012; Sukmiwati et al., 2012; Fadli et al., 2013; and Gasango et al.,2013). However information related to chemical composition and nutritional value of the Indonesian sea cucumbers are still limited. Numerous factors may influence the nutritional value of sea cucumbers which may also affect in their biopotency or bioactivity. The research was intended to inform on chemical composition and fatty acid profiles of the sea cucumbers represented by Bohadschia, Holothuria, Thelenota and Actinophyga that were abundant in surrounding 
Maluku, especially Halmahera Island. This information is expected to complete the previous information related to nutritional value of sea cucumbers .

\section{Material and Methods}

\subsection{Materials}

Sea cucumbers used in this study were collected by professional SCUBA divers in April 2014 from Halmahera waters in North Halmahera, North Maluku, Indonesia. Four types of sea cucumbers were collected and coded as $\mathrm{H}-03, \mathrm{H}-04, \mathrm{H}-05$ and $\mathrm{H}-10$. The sea cucumbers were collected, frozen overnight and transported to Jakarta using crushed ice in a styrofoam box. It took about 5 hours to bring the samples from Halmahera to the RCMFPPB laboratory in Jakarta. After keeping overnight in a cold storage, their size were measured and eviscerated, then kept in a cold storage for about one month before being analyzed. For identification, whole sea cucumbers (without eviscerating) were sent to Faculty of Fisheries and Marine Science, Bogor Agricultural University, Bogor, Indonesia. The identification was done based on their morphological characters and types of spicules. The harvesting regions of sea cucumbers is shown in Figure 1.

\subsection{Method}

Frozen sea cucumber samples were thawed, cut into small cubes, then minced for chemical composition analysis using method of SNI (2006). Moisture content was determined according to SNI 01-2354.2-2006 by drying samples in an oven at
$150{ }^{\circ} \mathrm{C}$ until constant weight (for about $16-24$ hours). Ash content was determined by incineration in a muffle furnace at $550^{\circ} \mathrm{C}$ for 8 hours (SNI 01-2354.1-2006); protein was analyzed using method of SNI 012354.4 2006 by Kjeltec ${ }^{\circledR} 2300$ Analyzer Unit; and lipid was determined according to SNI 01 2354.3 2006. Analysis was performed in twice replicates, except of $\mathrm{H}-05$ sample.

For fatty acid analyses, the minced samples were frozen and freeze-dried to obtain the dried product. Fatty acid (FA) profiles were analyzed by GC-FID based on fatty acids methyl ester (FAME) synthesis developed by O'Fallon et al. (2007) with slightly modification.

A $500 \mathrm{mg}$ dried sample was added with $2 \mathrm{ml}$ of $\mathrm{BF} 3$ in $\mathrm{MeOH}(14 \% \mathrm{v} / \mathrm{v})$ and incubated in a $55^{\circ} \mathrm{C}$ waterbath for $1.5 \mathrm{~h}$ with vigorous hand-shaking for $5 \mathrm{~s}$ every $20 \mathrm{~min}$. After being cooled, $2 \mathrm{ml}$ of HPLC grade $\mathrm{H}_{2} \mathrm{O}$ and $2 \mathrm{ml}$ of $\mathrm{n}$-Hexane was added to the solution. The upper layer containing the FAME was then concentrated under a concentrator until $100 \mu \mathrm{L}$. FAMEs were analyzed on an Agilent Technologies Gas Chromatography 7890A equipped with flame ionization detector (FID). Twenty $\mu \mathrm{L}$ of the FAME was injected in to the GC-FID system (split 50:1), on a HP-5 capillary column $(30 \mathrm{~m} \times 0.25 \mathrm{~mm}$ I.D. $)$. The initial oven temperature was $140^{\circ} \mathrm{C}$, held for $5 \mathrm{~min}$, subsequently increased to $240^{\circ} \mathrm{C}$ at a rate of $4{ }^{\circ} \mathrm{C} /$ $\mathrm{min}$, and then held for $20 \mathrm{~min}$. The carrier gas was Helium at a flow rate of $0.5 \mathrm{ml} \mathrm{min"1.} \mathrm{Both} \mathrm{the} \mathrm{injector}$ and the detector temperature were set at $260{ }^{\circ} \mathrm{C}$. Identification was done by comparison of the peak in the sample with fatty acid methyl standards (Supelco 37 Component FAME Mix in methylene chloride,

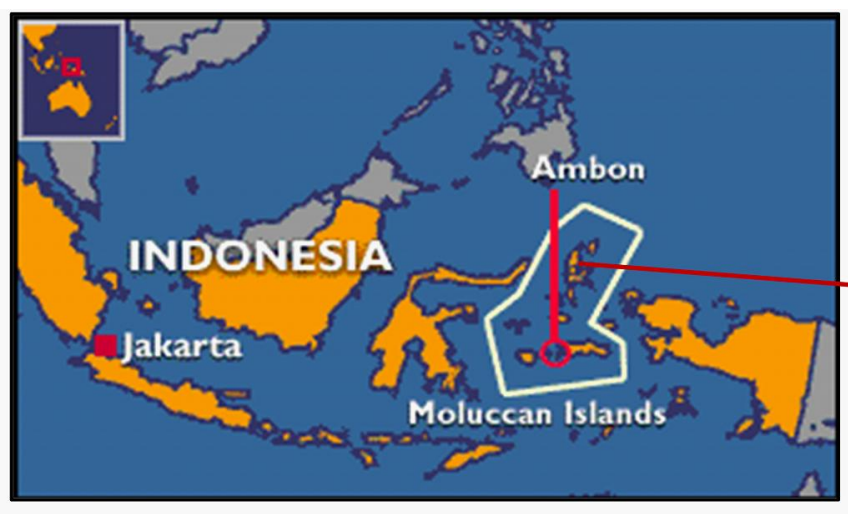

http://news.bbc.co.uk/2/hi/asia-pacific/806862.stm

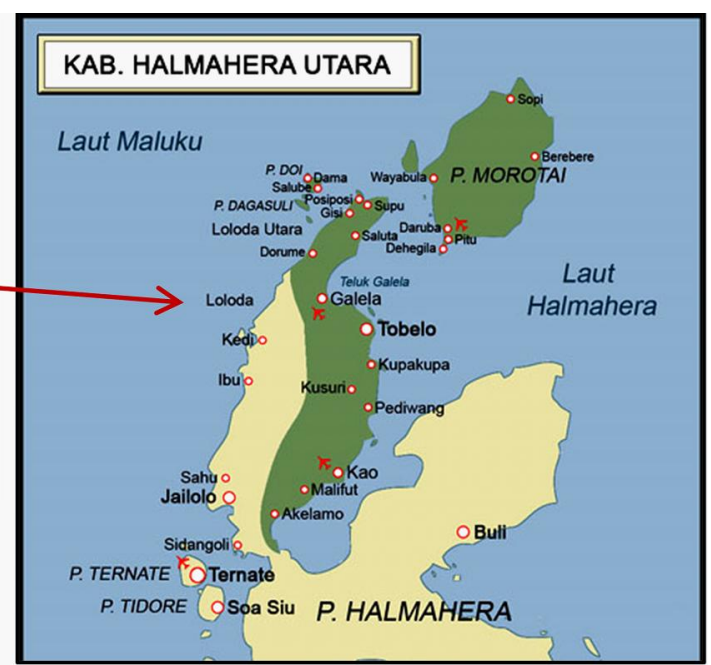

http://awigalelano.blogspot.com

Figure 1. The sampling location of sea cucumbers. 
Table 1. Size and identification results of sea cucumbers used in this study

\begin{tabular}{cccll}
\hline $\begin{array}{c}\text { Sample's } \\
\text { Code }\end{array}$ & Length $(\mathbf{c m})$ & Width $(\mathbf{c m})$ & \multicolumn{1}{c}{ Local name } & Identification results \\
\hline H-03 & $36,1 \pm 4,0$ & $11,5 \pm 2,2$ & Teripang benang bintik & Bohadschia argus \\
H-04 & $21,5 \pm 10,6$ & $9,8 \pm 4,5$ & Teripang susu & Holothuria fuscogilva \\
H-05 & 67 & 19 & Teripang kongkong & Thelenota ananas \\
H-10 & $16,6 \pm 5,5$ & $7,3 \pm 2,0$ & Teripang kapuk & Actinophyga lecanora \\
\hline
\end{tabular}

catalog $47885-U)$. Analyses of fatty acid profile was conducted with no replication.

\section{Results and Discussion}

\subsection{Morphometric Analysis}

Four sea cucumbers species were obtained and described as shown in Table 1. Among the samples, $\mathrm{H}-05$ identified as Thelenota ananas was a single sample and the biggest one with the length reached $67,0 \mathrm{~cm}$. According to Martoyo et al. (2010) the length of T.ananas could reach up to $100 \mathrm{~cm}$ with $6 \mathrm{~kg}$ in weight. Other samples coded as $\mathrm{H}-03, \mathrm{H}-04$ and $\mathrm{H}-$ 10 were identified as Bohadschia argus, Holothuria fuscogilva and Actinophyga lecanora respectively.

\subsection{Chemical Composition}

Chemical compositions of sea cucumbers are presented in Table 2. Moisture content varied from 84.34 to $90.81 \%$. In general, the results were similar with those found in previous studies reported by Özer et al. (2004); Aydin et al. (2011); Karnila et al. (2011); Omran (2013); which can be seen in Table 3. The most abundant chemical component was protein, which ranged from 48.26 to $68.75 \% \mathrm{db}$. B.argus contained the highest protein compared to the other. High protein content of B.argus $(62.1 \% \mathrm{db})$ was also reported by Wen et al. (2010). $T$ ananas showed the lowest content of protein. However, it contained the highest lipid content $(2.35 \% \mathrm{db})$ than that of other three species (less than $2 \% \mathrm{db}$ ). T. ananas was also found high in ash content $(37.40 \% \mathrm{db})$. Ash content may be related to mineral content like calcium, magesium, iron and zinc as describe by Chen (2003), Ridzwan (2007) and Bordbar (2011).

Proximate composition of fresh sea cucumbers may vary depending upon the species, seasonal variations in feeding behaviour and different region (Chang-Lee et al., 1989; Ginger et al., 2001; Bordbar et al., 2011). Based on several investigations it can be identified that proximate compositional data of fresh sea cucumbers vary widely as shown in Table 3 . It seems that eventhough species used in the studies were different, the results were found to be comparable.

\subsection{Fatty Acid Profiles}

Fatty acid profiles of investigated sea cucumbers are presented in Figure 3 to 5 . T. ananas showed the highest content and diversity of fatty acid, reached $17.059 \mathrm{mg} / \mathrm{g}$ samples which were distributed in 19 types of fatty acid. This was in accordance with the greatest fat content of T.ananas as presented in Table 2.

Based on chromatogram (data not shown) that peak showing C:18 coincide with C18:1n9t. However, considering with the investigation of Wen et al. (2010) and Aydin et al. (2011), that C:18 fatty acid (stearic acid) concentration in sea cucumbers is commonly higher compared to $\mathrm{C} 18: 1 \mathrm{n} 9 \mathrm{t}$ fatty acid (elaidic acid) concentration (about 3 to 6 times), so we assumed that the peak represented as C:18 (stearic acid).

Among total fatty acids, saturated fatty acid (SFA), especially palmitic acid (C16:0), was most dominant in T.ananas and H.fuscogilva (Figure $4 \& 5$ ). This is similar with Wen et al. (2010) investigation. They found that palmitic acid was the major fatty acid in T.ananas and H.fuscogilva, reached approximately $22 \%$ and $32 \%$ of total fatty acid respectively. Also, Ridzwan et al. (2014) found that palmitic acid was the main fatty acid contained in 3 species of Holothuria from Malaysian, with the amount of 34.2 to $52.7 \%$.

B.argus contained Saturated Fatty Acid, monounsaturated fatty acid (MUFA) and polyunsaturated fatty acid (PUFA) which was comparable each other (Figure 4). Wen et al. (2010) found that SFA was also the most abundant in $B$. argus, with the highest content of palmitic acid (approx. 15.8\%). Palmitic acid was the third abundant 
Table 2. Chemical composition of $B$. argus, H.fuscogilva, $T$. ananas and $A$. lecanora. The results are shown in mean $\pm \mathrm{SD}$

\begin{tabular}{lcccc}
\hline \multicolumn{1}{c}{ Composition } & B. argus & H. fuscogilva & T. ananas & A. lecanora \\
\hline Moisture $(\% \mathrm{wb})$ & $85.82 \pm 0.09$ & $84.34 \pm 0.72$ & $90.81 \pm 2.08$ & $87.78 \pm 0.95$ \\
Ash $(\% \mathrm{db})$ & $20.30 \pm 0.41$ & $30.45 \pm 6.79$ & $37.40 \pm 4.60$ & $23.03 \pm 2.95$ \\
Fat $(\% \mathrm{db})$ & $1.34 \pm 0.30$ & $1.12 \pm 0.28$ & 2.35 & $1.76 \pm 0.04$ \\
Protein $(\% \mathrm{db})$ & $68.75 \pm 17.29$ & $63.64 \pm 4.56$ & $48.26 \pm 2.32$ & $65.53 \pm 11.77$ \\
\hline
\end{tabular}

${ }^{*}$ Note: $w b$ : wet base; $\mathrm{db}$ : dry base.

Table 3. Proximate composition of fresh sea cucumbers

\begin{tabular}{|c|c|c|c|c|c|}
\hline Sea cucumbers & $\begin{array}{l}\text { Moisture } \\
(\%)\end{array}$ & $\begin{array}{c}\text { Ash } \\
(\% \mathrm{db})\end{array}$ & $\begin{array}{c}\text { Fat } \\
(\% \mathrm{db})\end{array}$ & $\begin{array}{l}\text { Protein } \\
(\% \mathrm{db})\end{array}$ & References \\
\hline Holothuria sp. & $81.2-87.2$ & $14.84-58.51$ & $0.70-5.64$ & $45.31-52.66$ & $\begin{array}{l}\text { Aydın et al., 2011*, Ozer et } \\
\text { al., 2004*,Omran, 2013, } \\
\text { Karnila et al., 2011* }\end{array}$ \\
\hline Bohadschia sp. & 83.2 & 6.03 & 4.83 & 43.23 & Omran, 2013 \\
\hline Actinophyga sp. & 84.7 & 2.12 & 4.99 & 48.27 & Omran, 2013 \\
\hline
\end{tabular}

${ }^{*}$ Note : Data were converted to \%db for ash, fat and protein content.

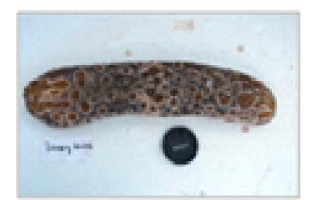

H 08 Bohadsehie argus

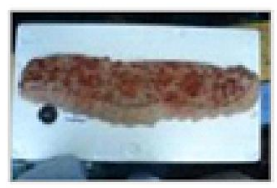

H 05 Thederoita ananas

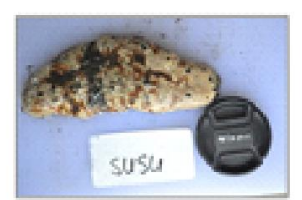

H 04 Foothuris fuscogina

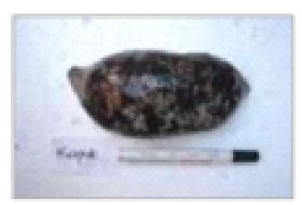

H10 Actinowos jeanora

Figure 2. Sea cucumbers collected from Halmahera Island, North Maluku, Indonesia.

fatty acid content in B.argus from Halmahera Island. The highest SFA of B.argus was heptadecaonate similar with A.lecanora, however this fatty acid was not the main fatty acid contained in these two sea cucumbers. The most abundant fatty acid contained in $B$. argus and $A$. lecanora was Eicosanoate and cis11,14-Eicosadienoic acid respectively which were unsaturated fatty acid.

Some essential fatty acids were observed in the samples, including omega- 3 and omega- 6 fatty acids, linoleic acid (LA) or C18:2n6c and alpha-linolenic acid (ALA) or C18:3n6 and eicosapentaenoic acid (EPA) or C20:5n-3. Long-chain $n-3$ fatty acids are well known as a nutrition having an important role in growth and development of brain function reducing the risk of coronary heart disease, cancer, inflammation, and arthritis (Ruxton et al., 2014; Boardbar et al., 2011). EPA was available in a limited amount and comparable for each sea cucumber investigated, with the content was in the range of $0.11-0.14 \mathrm{mg} / \mathrm{g}$ sample (Figure 4) or about 0.8 to $2.4 \%$ of total fatty acids. This amount was similar to the investigation of Ridzwan et al. (2014). Results showing that EPA content of four sea cucumber species (3 Holothurias and 1 Stichopus) from Malaysia was varied from $0.17-1.34 \%$ of total fatty acids. While DHA was not detected except in $S$. 


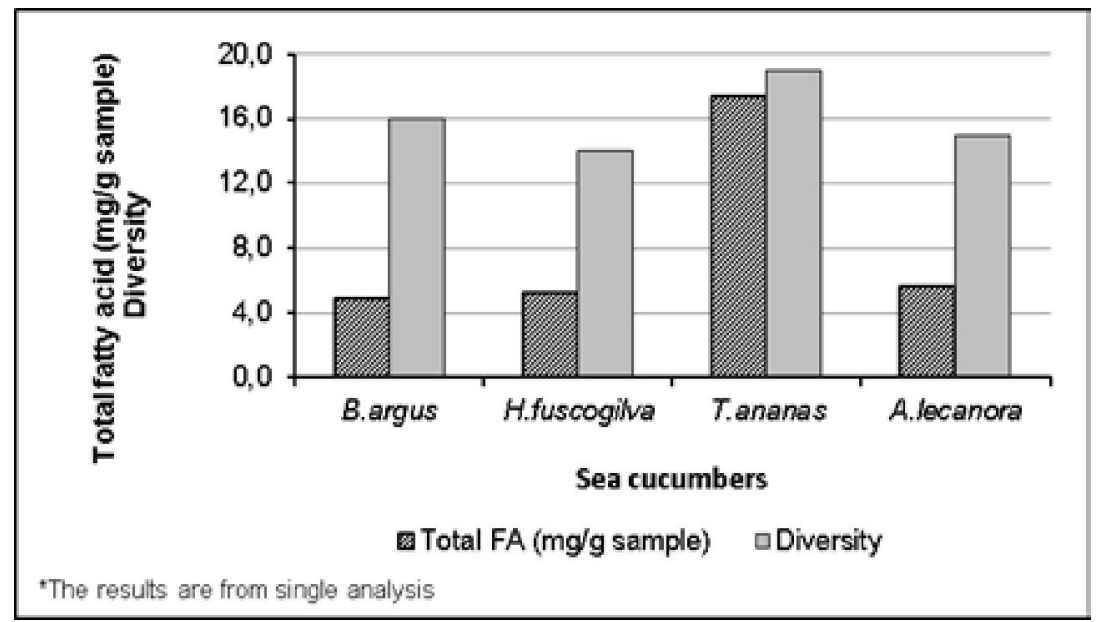

Figure 3. Total fatty acids and their diversity of $B$. argus, H.fuscogilva, T. ananas and A. lecanora from Halmahera.

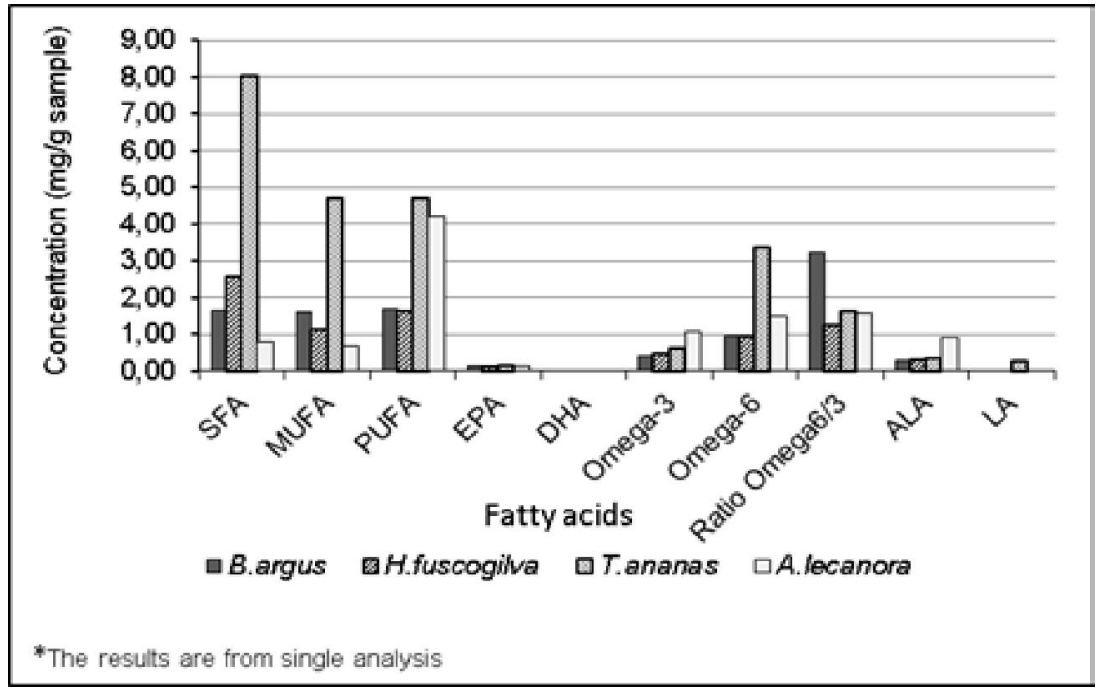

Figure 4. Content of SFA, MUFA, PUFA and some essential fatty acids of $B$. argus, H.fuscogilva, $T$. ananas and $A$. lecanora from Halmahera.

horrens with a low DHA content, only $0.32 \%$. Whereas, the result of this study showed that no DHA detected in the four sea cucumber samples.

Different result was reported by Aydin et al. (2011) who found that EPA content of Holothuria sp. reached about $4.6-9.3 \%$ of total fatty acids. However previous research investigated by Drazen et al. (2008) and Zhong et al. (2007) resulted significant amount of EPA in sea cucumbers. High concentration of EPA in deepsea echinodermis reached up to $9-18 \%$ of total fatty acids (Drazen et al., 2008), and very high EPA content was detected in C.frondosa from Newfoundland (Canada), with the range of $43 \%$ to $57 \%$ (w/w) (Zhong et al., 2007). According to Neto et al. (2006) and Aydin et al. (2011) dietary sources may influence on lipid biochemistry of sea cucumbers which further response in variation of fatty acids contained. The difference EPA content of the above results seems to be related with Valentine and Valentine (2010) statement that commonly cold-water marine species tend to accumulate higher amounts of long-chain $n-3$ fatty acids, particularly EPA and DHA (docosahexaenoic acid; 22:6n-3), than species found in temperate climate.

Ratio of $\omega-6 / \omega-3$ is an important index of the fatty acid which related to human health. Due to the antagonistic effects of omega- 6 and omega- 3 fatty acids, a balanced ratio of $\omega-6 / \omega-3$ should be applied into diet. According to GB Health watch (2013) increase in intake of omega- 6 will interfere with the proper function of omega-3 fatty acids, and then improve the risk in suffering disease related to chronic 

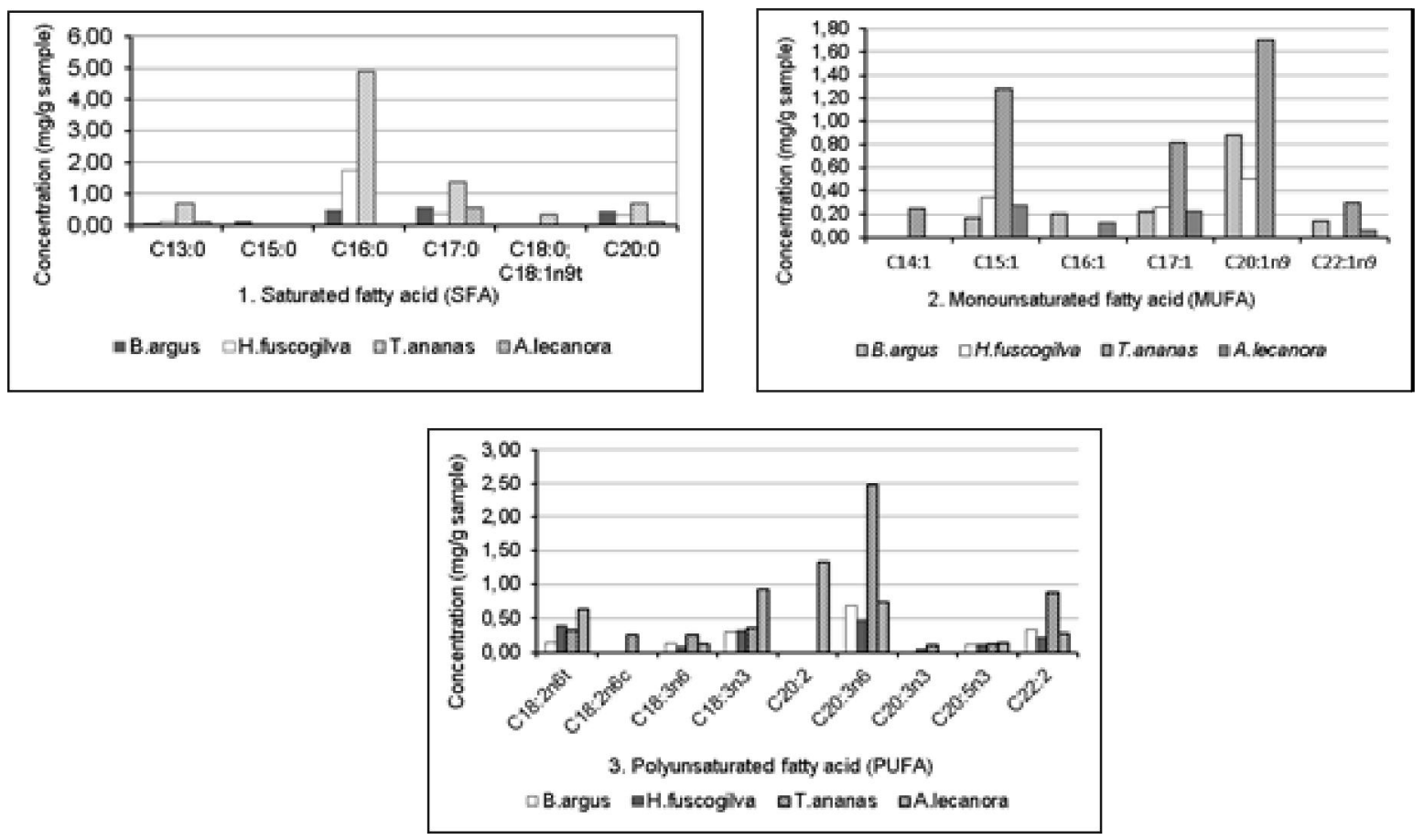

${ }^{*}$ The results are from single analysis

Figure 5. Fatty acid profiles: Saturated fatty acid (1), Monounsaturated fatty acid (2) and Polyunsaturated fatty acid (3) of $B$. argus, H.fuscogilva, $T$. ananas and and $A$. lecanora from Halmahera.

cardiovascular diseases and inflammatory response. The diet on which human beings evolved has a ratio of omega- 6 to omega- 3 of approximately 1 (Simopoulos, 2002). Modern Western diets was reported having omega-6:omega-3 ratios ranging between $15: 1$ to $17: 1$ which promoted the development of many chronic diseases (GB Health watch, 2013). For preventing certain disease such as cardiovascular, FAO recommended the optimal balance for $\omega-6 / \omega-3$ ratio in the diet should be between 5:2 and 8:1 (FAO/WHO, 2003). The $\omega-6 / \omega-3$ ratio of the sea cucumbers resulted from this research was in the range of $1,2-3,2$, which is safe for consumption and in the range of $\omega-6 / \omega-3$ ratio in sea cucumbers reported in several publication, i.e varied from 0.5-4.8 (Drazen et al., 2008; Wen et al., 2010; Telahigue et al., 2014; Haider et al., 2015).

As the omega- 3 fatty acids of sea cucumbers contained in a significant amount and susceptible to oxidation, a proper handling of the sea cucumbers should be done to keep fresh until being consumed. Other dosage forms may be prepared such as tablet, capsule or emulsion containing sea cucumber's extract which is rich in omega-3 fatty acids, to get the health benefits of the fatty acids in ameliorating the risk of certain diseases. This product may be consumed as food supplement or nutraceutical with or without addition of herbs to enhance the impact on human health. The recent finding showed that sea cucumber are new sources of phospholipid bonded omega-3 PUFA which is potential to target insulin resistance and obesity (Vaidya \& Chiima, 2014).

\section{Conclusion}

Sea cucumbers obtained from Halmahera, North Maluku, Indonesia contained high protein and low fat. This invertebrate was also rich in minerals shown by high in ash content. Except of $A$. lecanora, investigated sea cucumbers were dominant in SFA compared to PUFA or MUFA. However, all sea cucumbers contained of $\omega 3$ and $\omega 6$ fatty acids with the ratio of $\omega 6 / \omega 3$ was $1.2-3.2$, relatively low which is good for prevention of chronic diseases.

\section{Acknowledgement}

The authors are grateful for Dr. Dewi Seswita Zilda who has supported in sampling.

\section{References}

Aminin, D.L., Menchinskaya, E.S., Pisliagin, E.A., Silchenko, A.S., Avilov, S. A., \& Kalinin, V. I. (2015). Anticancer activity of sea cucumber triterpene glycosides. Review. Mar. Drugs 13, 1202-1223; doi:10.3390/md13031202. www.mdpi.com/journal/ marinedrugs. 
Anonymous. (2010). Potensi Teripang dan Segudang Manfaatnya. http://bisnisukm.com/potensi-teripangdan-segudang-manfaatnya.html. Accessed in February 2015.

Aydin, M., Sevgili, H., Tufan, B., Emre, Y., \& Ko"se, S. (2011). Proximate Composition and Fatty Acid Profile of Three Different Fresh and Dried Commercial Sea Cucumbers From Turkey. Int J. Food Sci Tech., 46, 500-508.

Badan Standardisasi Nasional. 2006. SNI 01-2354(2006). Cara Uji Kimia pada Produk Perikanan.

Bordbar, S., Anwar, F., \& Saari, N. (2011). High-value Components and Bioactives from Sea Cucumbers for Functional Foods - A Review. Mar. Drugs 9, 1761 1805; doi:10.3390/md9101761.

Brown, E.O., Perez, M.L., Garces, L.R.,Ragaza, R.J., Bassig, R.A., \& Zaragoza, E.C. (2010). Value Chain Analysis for Sea Cucumber in the Philippines. Studies \& Reviews 2120. The WorldFish Center, Penang, Malaysia. 44pp.

Chang-Lee, M.V., Price, R.J., \& Lampila, L.E. (1989). Effect of Processing on Proximate Composition and Mineral Content of Sea Cucumbers Parastichopus spp. J. Food Sci, 54(3): 567-572.

Chen, J. (2003). Overview of Sea Cucumber Farming and Sea Ranching Practices in China. SPC Bechede-mer Inf. Bull, 18, 18-23.

Darsono, P. (2007). Teripang (Holothurioidea): Kekayaan alam dalam keragaman biota laut. J. Oseana XXXII (2): 1-10.

Drazen, J.C., Charles F., Phleger, C.F., Guest, M.A., \& Nichols, P.D. (2008). Lipid, sterols and fatty acid composition of abyssal holothurians and ophiuroids from the North-East Pacific Ocean: Food web implications. Comp Biochem Physiol 151:79-87.

Elfidasari, D., Noriko, N., Wulandari, N., \& Perdana, A.T. (2012). Identifikasi Jenis Teripang Genus Holothuria Asal Perairan Sekitar Kepulauan Seribu Berdasarkan Perbedaan Morfologi. Jurnal Al-Azhar Indonesia Seri Sains dan Teknologi (1)3 : 140-146.

Fadli, M., Suryanti, \& Ruswahyuni. (2013). The Abundance of Sea Cucumbers Type (Holothuroidea) on The Coral Reef Flat And Coral Reef Slope of Pancuran Belakang Beach Karimunjawa Islands Jepara. Diponegoro Journal of Maquares, (2)3 :288-297.

FAO/WHO. (2003). Diet, nutrition and the prevention of chronic disease. Technical Report Series 916. Food and Agriculture Organization/World Health Organization, Geneva. 149 pp.

Gasango, H., Manu, G. D., \& Tamanampo, J. FWS. (2013). Community Structure of Cucumber (Holothuroidea) in Kakara Island Village Beach Subdistrict Tobelo. Jurnal IImiah Platax, 1(4), 187-195.

GB HealthWatch. (2013). Omega-3: Omega-6 balance. http://www.gbhealthwatch.com/Science-Omega3Omega6.php. Accessed in March 2015.

Ginger, M. L., Billett, D. S. M., \& Mackenzie, K.L. (2001). Organic matter assimilation and selective feeding by holothurians in the deep sea: some observations and comments. Progress in Oceanography, 50, 407421.
Haider, M. S., Sultana, R. S., Jamil, K., Lakhte, Zehra, Tarar, M., Shirin, K., \& Afzal, W. (2015). A study on proximate composition, amino acid profile, fatty acid profile and some mineral contents in two species of sea cucumber. J Anim Plant Sci. 25(1):168-175.

Januar, H. I., Nursid, M., \& Chasanah, E. (2014). Cytotoxic saturated fatty acids from the Indonesian sea cucumber Holothuria sp. Squalen Bulletin of Marine \& Fisheries Postharvest \& Biotechnology, 9 (1) : 1115.

Jiang, Y., Yao, L., Li, F., Tan, Z., Zhai, Y., \& Wang, L. (2014). Characterization of antimicrobial resistance of Vibrio parahaemolyticus from cultured sea cucumbers (Apostichopus japonicas). Lett. Appl. Microbiol. 59 (2):147-54. doi:10.1111/lam.12258.

Karnila, R., Astawan, M., \& Wresdiati, T. (2011). Potency of extract, hydrolysate and protein isolate of Holothuria scabra for decreasing blood glucose content and improve pancreatic beta cell profil of diabetes mellitus rat. (In Indonesian). Laporan Penelitian Hibah Bersaing Bidang Kesehatan. Universitas Riau Pekanbaru.

Martoyo, J., Aji, N., \& Winanto, T. (2006). Budidaya Teripang (Edisi Revisi). Penebar Swadaya. Jakarta

Neto, R.R., Wolff, G.A., Billett, D.S.M., Mackenzie, K.L. \& Thompson, A. (2006). The influence of changing food supply on the lipid biochemistry of deep-sea holothurians. Deep-sea Research 1, 53.

O'Fallon, J. V., Busboom, J. R., Nelson, M. L., \& Gaskins, C.T. (2007). A direct method for fatty acid methyl ester synthesis : Application to wet meat tissues, oils and feedstuffs. J Anim Sci 85 : 1511-1521. doi : 10.2527/ jas.2006-491.

Omran, N.S. (2013). Nutritional value of some Egyptian sea cucumbers. Afr. J. Biotechnol 12(35) : 54-66. ol. 12(35), pp. 54 DOI: 10.5897/AJB2013.13020.

Özer, N.P., Sühendan, Mol, S., \& Varlýk, C. (2004). Effect of the Handling Procedures on the Chemical Composition of Sea Cucumber. Turkish J. Fish Aquat. Sci. 4: 71-74.

Purwati, P. (2005). Teripang Indonesia : Komposisi jenis dan Sejarah Perikanan. Oseana XXX(2): 11-18

Ridzwan, B.H. (2007). Sea Cucumbers, A Malaysian Heritage, 1st ed.; Research Centre of International Islamic University Malaysia (IIUM): Kuala Lumpur Wilayah Persekutuan, Malaysia, pp. 1-15, 89-128.

Ridzwan, B.H. Hanita, M.H., Nurzafirah, M., Norshuhadaa, S.M.P., \& Hanis, Z.F. (2014). Free Fatty Acids Composition in Lipid Extracts of Several Sea Cucumbers Species from Malaysia. Int. J. Biosci, Biochem. Bioinforma, (4)3: 201-207.

Ruxton, C.H.S., Reed, S. C., Simpson, M. J. A., \& Millington, K.J. (2004). The health benefits of omega3 polyunsaturated fatty acids: a review of the evidence. The British Dietetic Association Ltd. J Hum Nutr Dietet, 17, pp. 449-459.

Simopoulos AP. (2002). The importance of the ratio of omega-6/omega-3 essential fatty acids. Biomed Pharmacother. 56(8):365-379.

Sukmiwati, M., Salmah, S., Ibrahim, S., Handayani, D., \& Purwati, P. (2012). Keanekaragaman Teripang (Holothuroidea) di Perairan Bagian Timur Pantai 
Natuna Kepulauan Riau. Jurnal Natur Indonesia. 14(2): 131-137.

Telahigue, K., Hajji, T., Imen1, R., Sahbi, O., \& El Cafsi, M. (2014). Effects of Drying Methods on the Chemical Composition of the Sea Cucumber Holothuria forskali. The Open Food Science Journal, (8) 1-8.

Valentine, R. C., \& Valentine. D. L. (2010). Omega-3 fatty acids and the DHA principle. CRC Press Inc., Boca Raton, FL. Pp. 69-92.

Vaidya, H. \& Cheema, S.K. (2014). Sea cucumber and blue mussel: new sources of phospholipid enriched omega-3 fatty acids with a potential role in 3T3-L1 adipocyte metabolism. Food Funct.5(12): 3287-95. doi: 10.1039/c4fo00330f.

Wen, J., Hua, C., \& Fana, S. (2010). Chemical composition and nutritional quality of sea cucumbers. J. Sci. Food Agric. 90: 2469-24745. doi.10.1002/ jsfa.4108.
Wen, J. \& Hua, C. Elemental composition of commercial sea cucumbers (holothurians), Food Additives \& Contaminants: Part B: Surveillance, 3:4, 246-252, DOI: $10.1080 / 19393210.2010 .520340$.

Yusron, E. (2004). Sumberdaya teripang di perairan Tanjung Pai Padaido Biak Numfor Papua. Makara Sains, (8)3: 123-127.

Zhang, Y. \& Yi, Y. (2011). Studies on antitumor activities of triterpene glycoside colochiroside $A$ from sea cucumber Colochirus anceps (Abstract; Article in Chinese). Zhongguo Zhong Yao Za Zhi. 36(4):504507.

Zhong, Y., Khan, M.A., \& Shahidi, F. (2007). Compositional Characteristics and Antioxidant Properties of Fresh and Processed Sea Cucumber (Cucumaria frondosa). J. Agric. Food Chem. 2007, 55, 1188-1192. 